\title{
As Parcerias Público-Privadas: Solução ou Problema?
}

\author{
Gilson Dantas de Santana* \\ dantas_dr@yahoo.com.br \\ Hélio de Souza Rodrigues Júnior ${ }^{\dagger}$ \\ rodrigues.helio@terra.com.br
}

\section{RESUMO}

O objetivo deste artigo é fazer uma crítica às parcerias público-privadas (PPPs). A primeira parte do texto busca transmitir uma idéia ampla das PPPs. As informações aí contidas não se aplicam inteiramente e com perfeição de encaixe ao caso brasileiro, mas também não o contradiz, pois as diferenças seriam pequenos ajustes formais, de modo que as concepções econômica, administrativa, jurídica e política, todas entrelaçadas, servem como instrumento para a compreensão da crítica formulada no momento seguinte. A crítica está delimitada por cinco pontos cruciais em qualquer avaliação menos ligeira às PPPs: a idéia de PPP cria demasiadas facilidades para o capital privado; compromete a própria essência daquilo que se chama de serviço público; favorece um tipo de política pública que já não será mais universal e sim focal; e, finalmente, representa a mercantilização dos serviços públicos típicos ou promovidos exclusivamente pelo Estado e viabilizam o interesse do capital financeiro internacional. Na última parte, fechamos o artigo com um elemento final de reflexão já incluso desde a primeira linha da análise. É que, a bem da verdade, a título de considerações finais, tecemos uma crítica à relação Estado-capital que, justamente, está manifesta nas PPPs.

Palavras-chave: parcerias público privadas; relação entre Estado e capital; mercantilização dos serviços públicos

\section{The Public-Private Partnership: Solution or Problem?}

\section{ABSTRACT}

The aim of this paper is to criticize the public-private partnership (PPPs). The first part of the text tries to transmit a wide idea of the PPPs. The information is not entirely applied perfectly to the Brazilian issue, but also does not contradict it because the differences would be small formal of adjustments so that the economical, administrative, juridical and political conceptions, all of them blended, serve as an instrument to the understanding of the formulated criticism in the following moment. The criticism is delimitated by five crucial points in any slightly evaluation of the PPPs; the idea of PPPs creates excessive facilities to the private capital; compromises the own essence of what is called public service or promotes exclusively by the State and makes viable the interest of the international financial capital. To conclude, the paper deals with the real face of the PPPs.

Key words: State-capital relationship - public/private partnership - capitalization of the public services

\footnotetext{
* Doutor em sociologia pela Unb.

† Mestrando em Direito e Políticas Públicas pelo UniCEUB, especialista em Filosofia Política pela UFC; especialista em Direito Constitucional pela UNIFOR.
} 


\section{AS PARCERIAS PÚBLICO-PRIVADAS}

\subsection{Ampla caracterização}

O marco legal de criação das parcerias público-privadas (PPPs) para a União foi a Lei $\mathrm{n}^{0}$ 11.079, de 30 de dezembro de 2004, que “institui normas gerais para licitação e contratação de parceria público-privada no âmbito da administração pública”. A legislação brasileira procurou inspirar-se na experiência estrangeira de países, como Espanha, Portugal e Inglaterra. Os britânicos têm experiência maior no campo das PPPs, tanto que especialistas em PPPs daquele país - PFIs, Project Finance Initiatives - assessoraram o governo Lula ${ }^{3}$ durante a tramitação da Lei no 11.079/2004 no Congresso Nacional.

As PPPs são definidas por uma grande empresa de consultoria especializada na matéria como um sistema de contratação de serviços públicos que regula as relações negociais, em contratos de longo prazo, entre o setor público e uma empresa privada ou um consórcio de empresas privadas, visando ao fornecimento de serviços públicos. A empresa ou o consórcio, geralmente assumem a responsabilidade pelo projeto, por exemplo, de engenharia, construção, operação e financiamento do empreendimento, com uma estrutura de alocação de riscos otimizadora dos recursos financeiros alocados (best Value for Money VfM). Portanto, sem discrepância com a definição legal e previstas no art. $2^{\circ}$ da mencionada legislação, as PPPs são uma “modalidade de delegação” de atribuições do Estado ao setor privado na qual entram recursos financeiros de ambas as partes e onde o Estado espera contar com a agilidade e a eficiência do empreendedor privado; ou, na definição do Ministério do Planejamento: PPPs são contratos entre o setor público e o privado com o objetivo de entregar um projeto ou um serviço tradicionalmente provido apenas pelo setor público para a esfera privada. (www.planejamento.gov.br/planejamento_investimento/conteúdo/notícias, acessado em 09 de setembro de 2005).

São apontados como as grandes utilidades das PPPs os projetos de infra-estrutura de longa maturação e que impliquem em grandes investimentos, ou seja, quando se trate de projetos que, normalmente, não atraem o empresariado privado, mas onde o Estado poderá, desde que ofereça certas garantias, mostrar-se capaz de atrair aquele investimento. Assim, diz-

\footnotetext{
${ }^{3}$ Chris Heathcote, da empresa Partnerships UK é um dos principais especialistas britânicos em PPPs, tem atuado como conselheiro junto ao governo brasileiro nos últimos meses, segundo o Valor Econômico de 24/3/04. Ao mesmo tempo, a grande multinacional Pricewaterhouse Cooper, líder mundial em PPPs, percorre gabinetes de ministros e governadores desde o início de 2003, procurando ganhá-los para as PPPs, como mostra reportagem do Correio Braziliense de 22/6/03.
} 
se que as PPPs têm um duplo objetivo: adotar um tipo de contrato e de "colaboração positiva” que articule a falta de recursos financeiros do Estado com a "eficiência de gestão do setor privado”; valer para áreas, como segurança pública, habitação, saneamento básico, infraestrutura viária, elétrica e outras áreas. Sobre este último aspecto, chamamos rápida atenção aqui para o art. $4^{\circ}$, inciso III da Lei $n^{0}$ 11.079, de 2004, em que são definidas áreas onde o uso das PPPs são vedadas, pois o curioso é que isso pode gerar duas interpretações: ou poderá ser visto como uma espécie de "lista”, tal como Gaston Jèze já observava que serviço público é definido pelo Estado e não pela natureza do serviço ${ }^{4}$; ou se pode entender que tal pequeno rol é apenas o reconhecimento da natureza desses serviços e que, por isso mesmo foi feito tal enumeração.

Podemos extrair, também, como objetivos ${ }^{5}$ dessa forma contratual entre o Estado e o particular que as PPPs:

i) visam reduzir os dispêndios orçamentários com investimento do setor público;

ii) transformam um dispêndio de capital (concentrado no início do projeto) em um dispêndio orçamentário de custeio (ao longo da vida do projeto);

iii) maximizam o valor dos recursos alocados ao longo do projeto, por meio da mitigação dos riscos, maximização da eficiência e inovação na estruturação dos contratos;

iv) induzem o setor público a desenvolver políticas macroeconômicas e sociais, levando em conta a consistência destas e a eficiência nas compras de bens e contratação de serviços;

v) induzem o setor privado a prestar serviços visando à racionalização dos custos e o atendimento na qualidade exigida;

vi) levam o setor público a definir suas prioridades por metas desejadas (outputs), delegando ao setor privado a escolha dos meios (inputs).

No mesmo passo são enumerados como princípios ${ }^{6}$ das PPPs, inclusive englobando as diretrizes previstas no art. $4^{\circ}$ da Lei ${ }^{\circ} 11.079$, de 2004:

(i) a criação de um mecanismo de pagamento pelo setor público, direta ou indiretamente, para entidades do setor privado, prestadoras de serviços públicos, na qual os desembolsos são realizados de acordo com a execução e a qualidade dos serviços prestados pelo concessionário;

(ii) a especificação prévia detalhada da produção e distribuição dos bens e serviços, bem como a definição clara da qualidade requerida;

\footnotetext{
${ }^{4}$ Vide capítulo V, “creación, organización e supresión de un servicio público”, de Gaston Jèze, do livro "principios generales del derecho administrativo".

5 Dados colhidos da empresa de consultoria KPMG Structured Finance S/A.

${ }^{6}$ Idem.

Prismas: Dir., Pol. Pub. e Mundial., Brasília, v. 3, n. 1, p. 148-181, jan.jun. 2006 
(iii) o valor do projeto é mensurado em termos de custos ajustados ao risco e ao longo da vida do projeto;

(iv) a identificação precisa dos riscos e o estabelecimento de seus mitigantes;

(v) a mudança radical na cultura e no ambiente organizacional do setor público - há impacto da cultura do operador privado sobre a cultura usual do serviço público;

(vi) o cumprimento rigoroso dos cronogramas de desembolso e execução de obras - quiçá com previsão de multas por atraso ou por performance abaixo do padrão mínimo;

(vii) a contabilização de passivos de longo prazo recorrentes, não facilmente identificáveis, evitando tomar decisões que contemplem unicamente políticas de curto prazo baseadas em regime de caixa.

Deste modo, são apresentados ${ }^{7}$ como pré-requisitos para as PPPs:

- a existência de apoio político a fim de garantir a continuidade e a previsibilidade dos negócios;

- uma lei e regulamentação que viabilize a implementação dos projetos;

- a criação de expertise pelos agentes públicos e privados;

- a definição de fluxos de caixa previsíveis e adequados; a otimização da estrutura contratual, com a inclusão de cláusulas de alteração contratual flexíveis, para adaptar as condições iniciais às mudanças de conjuntura, evitando indexação automática e distorções não previstas no início do contrato.

A motivação para a criação das PPPs foi a de que o Estado brasileiro não dispõe de recursos para grandes investimentos na área pública. Não conta com caixa para projetos de infra-estrutura tão necessários para o crescimento da economia brasileira e para os grandes projetos e investimentos na área social. As PPPs pretendem ser uma ferramenta poderosa para mobilizar a iniciativa privada em parceria com o Estado, no sentido de, juntos, tocarem obras sociais e de infra-estrutura, desde estradas, energia elétrica, hospitais a penitenciárias. O ponto central que sempre envolveu o programa foram polêmicas sobre a pressão por mais concessões e garantias de parte do setor privado em relação ao governo, daí a advertência de Werneck:

“É preciso ter em conta, em primeiro lugar, que o cerne da proposta - a garantia pelo governo de um mínimo de rentabilidade em investimentos de retorno baixo ou paticularmente incerto - é uma idéia bastante velha. No Brasil, tem pelo menos 150 anos. Em 1852, quando Pedro II ainda era um jovem monarca, o governo imperial promulgou legislação que assegurava retorno mínimo de 5\% ao ano a investimentos em ferrovias. Em muitos casos a rentabilidade garantida chegou a $7 \%$, à medida que governos provinciais se dispuseram a conceder estímulos adicionais. Ainda no século 19, esse mesmo esquema de incentivo foi utilizado em outras áreas. Em

\footnotetext{
${ }^{7}$ Idem. 
1875, por exemplo, foi aplicado a um programa de modernização do setor açucareiro no Nordeste, que previa a construção de uma rede de engenhos centrais, que introduziriam tecnologia mais avançada e assegurariam mercado a pequenos produtores de cana. Programa que, apesar da rentabilidade assegurada pelo governo, acabou sendo um completo fracasso. Cem anos depois, em meados da década de setenta do século passado, a idéia de garantia de rentabilidade mínima pelo governo havia sido completamente abandonada. Os esquemas de parceria público-privada tinham assumido outros formatos. De um lado, havia o modelo do terço. Empresas em que o governo se associava ao capital estrangeiro e ao capital privado nacional. De outro, tinha-se o BNDES, pronto a subscrever ações de empresas privadas e a conceder empréstimos de longo prazo com teto de correção monetária de $20 \%$ ao ano". (WERNECK, Jornal O Estado de São Paulo de 24 de outubro de 2003).

Se, dessa nota, podemos perceber que, a rigor, sob o enfoque econômico, as PPPs representam uma “idéia bastante velha, que no Brasil tem pelo menos 150 anos”, também pelo enfoque jurídico, esse instrumento caminha muito mais na direção de buscar atender a uma demanda específica dos interesses empresariais envolvidos do que ser a instauração de um elemento novo na seara do Direito Administrativo, pois, conforme nos diz Carlos Bastite Horbach:

\begin{abstract}
"as parceria público-privadas são mais uma técnica de administração do que um novo instituto jurídico que mereça normatização própria e específica no Direito brasileiro, há de se indagar o porquê do desenvolvimento de toda uma conformação jurídica específica para regulá-las. A resposta a essa pergunta parece residir em questões mercadológicas. Ao se consagrar no ordenamento jurídico brasileiro uma forma de colaboração com a qual os investidores estrangeiros estão mais acostumados, com os mesmos nomes, com os mesmos 'bordões', pretende-se tornar mais palatáveis os investimentos de vulto na infra-estrutura pública nacional. Trata-se, portanto, de um 'disfarce' que a velha concessão passa a utilizar, para fazer crer ao investidor estrangeiro que todos os riscos que eram por ele suportados, sejam eles cambiais, contratuais ou políticos, foram afastados, fazendo do Brasil um local de investimento seguro e de sua Administração um parceiro confiável. A pergunta que fica, como conclusão, é a seguinte: é esse recurso suficiente para ensejar a confiabilidade necessária aos investimentos? A resposta pode ser sintetizada numa frase de Pedro II sobre as diversas reformas eleitorais do Império: "Não é o vestido que tornará vestal a messalina, porém, sim, a educação do povo e, portanto, a do Governo'. (HORBACH, 2004).
\end{abstract}

As duas transcrições assinalam que o Estado tem que ter claro de que para que as PPPs funcionem a contento, ele precisa oferecer garantias especiais ao seu sócio privado. Essa sempre foi a linha do próprio discurso oficial sobre as PPPs. E está sendo agora, no seu processo de implementação de regulamentação do Fundo Gestor, consoante apresentaremos no capítulo seguinte. Importa aqui demonstrar que foi o ministro da Fazenda, Palocci, quem 
assumiu que "as PPPs não são uma panacéia” (Jornal Valor Econômico de 4 de fevereiro de 2004), ao mesmo tempo em que tinha sido o próprio Palocci quem mostrou toda disposição em criar facilidades para o parceiro privado ao declarar que o governo criaria um fundo fiduciário (como de fato está previsto na Lei $\mathrm{n}^{\circ}$ 11.079, de 2004, art. 16) baseado em ações do Tesouro, de forma que sejam propiciadas todas as garantias possíveis aos investidores privados (Jornal Valor Econômico de 5 de fevereiro de 2004). Assim é que, no tocante às garantias, o setor privado sempre se quedou duvidoso do Estado, afinal de contas, como nos lembra Werneck, ainda analisando as PPPs à luz do projeto em tramitação no Congresso nacional:

\begin{abstract}
"na longa história de utilização desse incentivo, são recorrentes os casos nos quais o setor público acabou enfrentando dificuldades para honrar o compromisso assumido. Para evitar problemas desse tipo, o projeto contempla a idéia de se conferir aos pagamentos envolvidos no cumprimento das garantias 'precedência em relação às demais obrigações contratuais contraídas pela Administração Pública'. Mesmo à luz dos padrões mais recentes de responsabilidade fiscal, é difícil evitar certo ceticismo quanto à eficácia dessa solução. Basta ter em conta o que ocorreu com o pagamento de precatórios estaduais nos últimos anos. O que a legislação prévia, no caso de dívidas judiciais, é que o Estado seria obrigado a inscrever o débito no orçamento para que fosse pago no exercício seguinte. O não pagamento poderia dar margem a intervenção federal. Difícil imaginar critério de precedência mais rigoroso do que esse. E o que ocorreu? Embora a maior parte das dívidas judiciais não tenha sido paga, não houve intervenção em qualquer Estado. Quando, em 2000, a situação parecia insustentável, o Congresso, pressionado pelos governadores e pelo Judiciário, simplesmente aprovou emenda constitucional permitindo o refinanciamento das dívidas judiciais pelo prazo de 10 anos. Ter essa experiência tão recente em mente pode ajudar a injetar mais realismo político na busca de soluções alternativas, que talvez permitam equacionar de outra forma a questão da qualidade das garantias”. (WERNECK, Jornal O Estado de São Paulo de 24 de outubro de 2003).
\end{abstract}

Todavia, o governo brasileiro sempre esperou que (e pediu aos) fundos de pensão brasileiros e também estrangeiros que invistam nas PPPs, argumentando que se constituirão num investimento "mais rentável que o do mercado financeiro" (Jornal Valor Econômico de 29 de outubro de 2003, grifo nosso), apesar de nossas taxas de juros; inclusive o presidente Mantega do BNDES já apontou recursos do próprio BNDES (Banco Nacional de Desenvolvimento Econômico e Social), do BID (Banco Interamericano de Desenvolvimento), fundos de pensão e bancos estrangeiros para financiamento das PPPs (Jornal Gazeta Mercantil de 25 de março de 2004), e, conforme veremos no capítulo seguinte, o então tão pleiteado fundo garantidor das PPPs já foi regulamentado. Assim, a idéia das PPPs, em síntese, é a de 
que, através do "compartilhamento de riscos” o setor privado assumirá parte do compromisso de investimentos públicos e, dessa forma, a realização de serviços ou empreendimentos públicos. O setor privado sempre fez eco ao empenho do governo pelas PPPs, ao mesmo tempo em que conseguiu clareza no marco regulatório, além de ter conseguido êxito em sua reivindicação de um sistema de garantias para seus lucros devidamente inscrito na lei.

\section{AS PARCERIAS PÚBLICO-PRIVADAS: SOLUÇÃO OU PROBLEMA?}

O lado positivo e de sucesso das PPPs costuma ser bem destacado tanto pela imprensa quanto pelo discurso oficial do governo. Dessa forma não fica muito evidente o impacto negativo que tais parcerias podem acabar tendo contra a economia nacional e a vida da população de conjunto.

A grande mídia (e boa parte dos estudos sobre o tema) ocultou (e ainda oculta) aspectos essenciais do problema e adota um enfoque parcial, quase sempre de cobrança por mais flexibilidade, mais garantias e mais abertura por parte do Estado, inclusive nessa fase de regulamentação da matéria. Esse tipo de parceria foi concebido pelo Ministério do Planejamento ao final do governo de $\mathrm{FHC}^{8}$, e como dito alhures, copiado da Inglaterra e, no Brasil, passou a ser simpaticamente chamado de parceria público-privada, inclusive tendo sido pouco divulgado os fatos de que a implantação das PPPs foi acordada pelo Ministro da Fazenda, Palocci, e a missão do FMI (Fundo Monetário Internacional) em fevereiro de 2004 (Jornal Diário da Tarde de 13 de fevereiro de 2004) e que a mesma equipe que formulou o projeto das PPPs para FHC em seu final de mandato, tocou o modelo mineiro das PPPs do governo tucano de Aécio Neves; sem falarmos naquela assessoria britânica.

A grande justificativa de quem defende as PPPs é, invariavelmente, o seu tom otimista e de fé no grande investidor, especialmente o investidor internacional. Ora, esse otimismo e essa fé passam a ter valor duvidoso se lembrarmos, por exemplo, que os setores onde o governo quer que o capital privado invista, não costumam ser de interesse desse mesmo capital. Isto é, o Estado terá que tornar tais empreendimentos bastante lucrativos para que o grande capital se interesse por eles. A dedução óbvia é a de que o futuro pode não ser nada bom se, de fato, a aplicação da Lei n 11.079, de 2004 e sua regulamentação transformar certos serviços públicos em mercadoria atrativa e bem lucrativa em termos de mercado, como

\footnotetext{
${ }^{8}$ Gestão presidencial de Fernando Henrique Cardoso, cujas iniciais de seu nome serviram para designar-lhe o período de governança, sendo de amplo e notório conhecimento. 
na expressão já utilizada: “mais lucrativas que o mercado financeiro”. Portanto, nessa crítica vamos nos ater a alguns pontos que são cruciais em qualquer avaliação menos ligeira ao projeto das PPPs. Vamos nos limitar a cinco dos males de que padecem as PPPs.

\subsection{Criação de Demasiadas Facilidades para o Capital Privado}

O primeiro deles é que a idéia de PPP, consubstanciada na Lei nº 11.079/2004, cria demasiadas facilidades para o capital privado. Sua linha geral é velha conhecida nossa dos anos FHC, seja nas privatizações, seja na legislação das concessões e outros tipos de vínculos Estado-setor privado: privatização dos lucros e estatização dos prejuízos; e isso sem falarmos nos riscos que são criados para o patrimônio, o endividamento e a receita da União conforme está explícito no texto da lei das PPPs, por exemplo, seja através do endividamento, via fundo, de até seis bilhões de reais (art. 16 da Lei $n^{0} 11.079$, de 2004), ou vinculação de receitas, contratação de seguro-garantia junto a companhias privadas, ou ainda, garantias prestadas por organismos internacionais ou instituições financeiras (art. $8^{\circ}$ da Lei ${ }^{\circ}$ 11.079, de 2004); sem falar do risco para o usuário em termos de tarifas altas (art. 5º incisos IV e V da Lei $n^{\circ} 11.079$, de 2004).

Assim é que em vários pontos da Lei n ${ }^{\circ}$ 11.079, de 2004 o Estado aparece, em seu poder decisório, como um parceiro menor ou empenhado em garantir, a todo custo, o sucesso do outro parceiro, mais ou menos como se o Estado brasileiro estivesse, de fato, tratando de servir ao grande capital e à sua acumulação privada ao promover essa modalidade de parceria. Aliás, em outros termos, esse termina sendo, na prática, o objetivo assumido pelo Estado, e como já salientado, foi o cerne principal do debate quando da criação das PPPs: é preciso dar toda garantia de lucratividade privada ao empreendimento.

Se percorrermos a lei das PPPs os exemplos nesse sentido são vários: o Estado aparece como um parceiro que poderá assumir as dívidas assumidas pelo setor privado; o Estado aparece, em termos de financiamento e garantia dos contratos das PPPs, na condição de um parceiro que admite que poderá arcar, total ou parcialmente, com os custos do investimento e com a remuneração esperada pelos investidores e até com grande parcela da tarifa cobrada ao usuário; o Estado se postula também como o parceiro que poderá efetuar o pagamento ao setor privado (a título de contraprestação) sob a forma de dinheiro mas também de "outorga de direitos sobre bens públicos dominicais”, títulos, ações de empresas públicas 
ou Sociedade de Economia Mista (desde que não coloque em risco a maioria das ações); o Estado igualmente se mostra como um parceiro que poderá ser o responsável pelo resgate de empréstimos assumidos junto a instituições financeiras em caso de dificuldades do seu parceiro privado. O mesmo Estado criou um fundo garantidor do projeto (fundo fiduciário) constituído não apenas por recursos orçamentários, mas por ativos nacionais móveis e imóveis: ou seja, nada impede que o Estado tenha que pagar ao setor privado, a título de contraprestação, com ações de estatais, mas também com bens da União que passariam a estar disponíveis para o setor privado neste fundo garantidor (fiduciário). Em suma: há problemas de todo tipo nessa linha de tentar seduzir o capital privado para entrar nas parcerias. Vejamos alguns exemplos na lei das PPPs:

\subsubsection{Art. 7º "caput” e parágrafo único}

Esse dispositivo fixa que a contraprestação da Administração Pública deve ser precedida da disponibilização do serviço objeto do contrato das PPPs. Isso aparentemente teria importância fundamental, já que a principal característica da PPP é a de que a remuneração do setor privado se daria apenas contra a prestação do serviço claramente especificado. Assim, em geral, nenhum pagamento seria feito durante a fase de construção da obra. Todavia, essa regra foi flexibilizada (PAIVA e ROCHA, 2005:30), facultando-se à Administração Pública, nos termos do contrato, efetuar o pagamento da contraprestação relativa à parcela fruível do serviço objeto do contrato (parágrafo único do art. $7^{\circ}$ ). Ou seja, como ensina a melhor técnica legislativa, o parágrafo de um artigo serviu para excepcionar o seu caput.

\subsubsection{Art. 27}

Alega-se que este dispositivo teve o objetivo de proibir que as PPPs fossem totalmente financiadas com recursos públicos, ou seja, uma "parceria público-pública”, em que o setor privado praticamente não arcaria com os riscos envolvidos no empreendimento. De forma a garantir a efetiva aplicação de recursos privados nas PPPs, se inclui na lei a previsão de que as operações de crédito efetuadas por empresas públicas ou sociedades de economia mista controladas pela União não poderão superar $70 \%$ das fontes dos recursos financeiros das sociedades de propósito específico (SPEs). Para as áreas das regiões Norte, Nordeste e Centro-Oeste com índice de desenvolvimento humano (IDH) inferior à média nacional, essa participação poderá ser mais elevada, de até 80\% (PAIVA e ROCHA, 
2005:30). É bom lembrar aqui a regra prevista no art. $9^{\circ}$ da Lei $n^{\circ} 11.079$, de 2004, no sentido de que antes da celebração do contrato, deverá ser constituída uma SPE, incumbida de implantar e gerir o objeto da parceria. Por conseguinte, é ótimo ser empreendedor e defender a livre iniciativa usando 30\% do capital privado no investimento e, nas regiões pobres, somente 20\%. Ao contrário do que alegam os que defendem as PPPs, esse dispositivo legal indica que o que se verifica aqui não é um exemplo típico de um Estado que não tem recursos, ou de que o empreendedor cumpre uma função social.

Por sua vez, se cogitou muito sobre atuação dos fundos fechados de previdência complementar patrocinados por empresas estatais nas PPPs, o que na verdade seria novo financiamento público (lato sensu) do Estado para o parceiro privado. Assim é que as operações de crédito ou contribuições de capital de entidades fechadas de previdência complementar e de empresas públicas ou sociedades de economia mista controladas pela União, por sua vez, não poderão superar $80 \%$ das fontes de recursos financeiros das SPEs (PAIVA e ROCHA, 2005:30). Nas áreas das regiões Norte, Nordeste e Centro-Oeste com IDH inferior à média nacional, esse limite é de $90 \%$ (§ $1^{\circ}$ do art. 27). Importante dizer que esse limite não abrange as empresas públicas ou sociedades de economia mista controladas pelas demais esferas de governo, até porque isso implicaria interferência em competências dos Estados e dos Municípios. Essa particularidade, entretanto, permite que surjam parcerias "público-pública” por meio da associação de capitais da União e das demais Unidades da Federação (PAIVA e ROCHA, 2005:30); além do fato de que, se o parceiro privado contar com financiamento de fundos fechados de previdência complementar patrocinados por empresas estatais, o ingresso de recurso privado é na ordem somente de $20 \%$, ou, nas regiões com IDH abaixo da média nacional, com 10\%.

\subsubsection{Art. 16}

O Fundo Garantidor de Parcerias Público-Privadas (FGP) tem como objetivo prestar garantia de pagamento de obrigações dos parceiros públicos federais nas PPPs. Sua finalidade precípua é a de ressarcir os parceiros privados de possíveis prejuízos no caso de incapacidade do poder público para honrar os compromissos assumidos nos contratos de parceria, conforme reza o próprio art. 16 da Lei $\mathrm{n}^{\circ}$ 11.079, de 2004. Uma das principais características do FGP é que ele não poderá ser objeto de contingenciamento orçamentário e 
de uso de seus ativos para honrar precatórios (PAIVA e ROCHA, 2005:30). Ocorre que diversos outros setores de políticas sociais podem (e normalmente são) objetos de contingenciamento orçamentário, o que importa significar que a prioridade não está sendo dada, por exemplo, nas áreas sociais, mas de eventuais pagamentos de garantias dadas, onde, diga-se de passagem, o Estado já ingressou com aporte de recursos para o parceiro privado. Previu-se, então, que o FGP terá natureza privada e patrimônio próprio separado do patrimônio dos quotistas ( $\left(1^{\circ}\right.$ do art. 16). Este ponto é importante, pois, como dito, garante que o fundo não estará sujeito a contingenciamento, bem como delimita claramente o risco a que estarão expostos os quotistas do setor público.

Por outro lado, foi estabelecido o limite de seis bilhões de reais para participação da União, de suas autarquias e fundações públicas na integralização de cotas do fundo. A integralização das cotas poderá ser realizada em dinheiro, títulos da dívida pública, bens imóveis dominicais e bens móveis, inclusive ações de sociedades de economia mista federal excedentes ao necessário para manutenção de seu controle pela União ( $\S 4^{\circ}$ do art. 16). Pelo fato de que o FGP não possuir personalidade jurídica e ter natureza privada, não será caracterizado como ente da Administração Pública. Eventual execução movida contra ele ocorrerá somente pelas regras do direito privado (ou seja, execução entre particulares). A lei estabelece, ainda, que, quando da aquisição de quotas, todo e qualquer bem a ser integralizado pela União deixa de ser de sua titularidade, passando ao domínio do fundo. Ou seja, os bens deixam de ser públicos para se tornarem privados, perdendo, assim, os atributos de impenhorabilidade, inalienabilidade e imprescritibilidade, que são próprios dos bens públicos.

Vale destacar que o FGP prestará apenas garantias para as PPPs contratadas no âmbito da União. Alguns Estados, como São Paulo e Goiás, ao invés de instituírem fundos nos moldes do FGP, optaram por criar companhias com a finalidade de administrar os ativos que servirão de garantias aos parceiros privados nas suas PPPs. A própria lei permite que as garantias de pagamento das obrigações da Administração Pública sejam prestadas por meio de fundo garantidor ou empresa estatal criada para essa finalidade, conforme dispõe o inciso $\mathrm{V}$ do art. $8^{\circ}$ da Lei das PPPs (PAIVA e ROCHA, 2005:30).

O Decreto do Presidente da República $n^{0} 5.411$, de 7 de abril de 2005, por sua vez, atribui ações de quinze empresas estatais ao FGP. Estimou-se que essas ações 
representassem de três bilhões e setecentos milhões a quatro bilhões. ${ }^{9}$ Os montantes alocados constam do quadro a seguir.

\begin{tabular}{|c|c|c|c|c|}
\hline \multicolumn{5}{|c|}{$\begin{array}{l}\text { Recursos para as PPPs } \\
\text { Papeis quesera ubados no fundo garantidor }\end{array}$} \\
\hline \multicolumn{5}{|c|}{ Açōes Depositadas em Fundos } \\
\hline Fundos & Empresas/espécie de aç & & Classe & Quantidade de açbles - unidades \\
\hline \multirow[t]{2}{*}{ FAD } & CTEEP & & ON & 9.556 .150 .967 \\
\hline & Elotropaulo & & CN & 3335.596 .142 \\
\hline \multirow[t]{9}{*}{ FND } & BB & & ON & 30.000000 \\
\hline & CVRD & & ON & 14.178 \\
\hline & & & PN & 15.226 .023 \\
\hline & Embraer & & ON & 1850494 \\
\hline & & & PN & 499.416 \\
\hline & Petrobras & & ON & 970.584 \\
\hline & Usiminas & & PNB & 365813 \\
\hline & Tractebel & & ON & 12425.061863 \\
\hline & & & PNB & 40.920 \\
\hline \multicolumn{5}{|c|}{ Demais açбes } \\
\hline \multicolumn{2}{|c|}{ Empresas/espécie de açî́o } & Clas & & Quantidadede açōes - unidlades \\
\hline \multicolumn{2}{|c|}{ Eletrobrás } & $\mathrm{ON}$ & & 20.000000000 \\
\hline & & PN & & 17595.501 .100 \\
\hline \multicolumn{2}{|l|}{ Coelba } & ON & & 14.004 .288 \\
\hline \multirow{2}{*}{\multicolumn{2}{|c|}{ Celpe }} & ON & & 38.267848 \\
\hline & & PN & & 122911656 \\
\hline \multicolumn{2}{|l|}{ Comgis } & ON & & 7.231564 \\
\hline \multirow{2}{*}{\multicolumn{2}{|c|}{ Coelce }} & ON & & 166.896 .894 \\
\hline & & PN & & $832.625,407$ \\
\hline \multicolumn{2}{|l|}{ Gerdau } & PN & & 182.547 .363 \\
\hline & & ON & & 9.578 \\
\hline \multicolumn{2}{|c|}{ Rhodia-Ster } & PN & & 163.288 \\
\hline & & PN & & 336.285 \\
\hline
\end{tabular}

Siglas: Banco do Brasil (BB), Centrais Elétricas Brasileiras (ELETROBRÁS), Companhia de Eletricidade de Pernambuco (CELPE), Companhia de Eletricidade do Estado da Bahia (COELBA), Companhia de Gás de São Paulo (COMGÁS), Companhia de Transmissão de Energia Elétrica Paulista (CTEEP), Companhia Energética do Ceará (COELCE), Companhia Vale do Rio Doce (CVRD), Eletricidade de São Paulo (ELETROPAULO), Empresa Brasileira de Aeronáutica (EMBRAER), Petróleo Brasileiro (PETROBRÁS) e Usinas Siderúrgicas de Minas Gerais (Usiminas) Fonte: Valor Econômico, 08/04/2005. (retirado do trabalho de PAIVA e ROCHA, 2005, p 30)

Apenas para fins de atualização do quadro, matéria publicada no Jornal Correio Braziliense de 16 de setembro de 2005 indica que o FGP será administrado pelo Banco do Brasil e é formado por ações de empresas como Petrobrás, Usiminas, Eletrobrás, Embraer, Vale do Rio Doce e do próprio Banco do Brasil, cotadas em quatro bilhões de reais, sendo que poderão ser alocadas novas ações, pois o limite fixado na legislação é de seis bilhões de reais.

\footnotetext{
${ }^{9}$ Fundo das PPPs terá papéis de 15 Empresas, Jornal Valor Econômico, de 8 de abril de 2005.
} 


\subsubsection{Art. $8^{\circ}$, incisos III e IV}

Outra forma para garantir o pagamento das obrigações pecuniárias contraídas pela Administração Pública é a contratação de seguro-garantia com companhias seguradoras que não sejam controladas pelo Poder Público (inciso III do art. $8^{\circ}$ ), bem como o uso de garantia de organismos internacionais (inciso IV do art. $8^{\circ}$ ), como assinalado anteriormente. Vale destacar que instituições como o Banco Mundial (BIRD) e o Banco Interamericano de Desenvolvimento (BID) já manifestaram interesse em participar de novos projetos de infraestrutura na América Latina. Essa participação poderá ser feita tanto por meio de concessão de crédito quanto pela prestação de garantias nos contratos das PPPs. O que, em dada medida, acarreta o endividamento externo do Brasil, e, inclusive, estamos novamente nos endividando, tal como na década de 70 pelos governos militares, para fazer infra-estrutura; sendo que com juros maiores do que na década de 70 (cujo crédito era fácil por causa dos petrodólares) e para, depois, novamente, vender o patrimônio como feito nas privatizações.

\subsubsection{Art. 10, $\$ 3^{\circ}$}

Esse dispositivo legal determina que dependerão de autorização legislativa específica as concessões patrocinadas em que mais de $70 \%$ da remuneração do parceiro privado for paga pela Administração Pública. É bom lembrar que concessão patrocinada é uma das modalidades de PPPs, onde a concessão de serviço público ou de obra pública envolve, adicionalmente à tarifa cobrada dos usuários, contraprestação pecuniária do parceiro público ao parceiro privado ( $\$ 1^{\circ}$ do art. $2^{\circ}$ da Lei $n^{\circ} 11.079$, de 2004). Assim, se criou a obrigatoriedade de se submeter ao crivo do Poder Legislativo as PPPs em que a complementação do setor público à tarifa cobrada do usuário é elevada (PAIVA e ROCHA, 2005:30). De qualquer forma, a autorização legislativa, frente a vida real e não a teoria abstrata do papel de um Parlamento, será uma mera burocracia sem efetivos questionamentos; além do que, repita-se, é bom ser investidor em um sistema de livre concorrência em que se exige somente $30 \%$ de capital para ser uma empresa com slogan do tipo: que investe no Brasil.

\subsubsection{Art. $5^{\circ}, \S 2^{\circ}$, inciso I}

Consta na lei das PPPs um sistema conhecido, na tradição jurídica anglo-saxônica, como step-in-rights, que permite aos financiadores da PPP assumirem o controle do 
empreendimento quando o parceiro privado não estiver cumprindo suas obrigações, de forma a promover a reestruturação financeira do projeto e assegurar a continuidade dos serviços contratados, consoante inciso I do $\S 2^{\circ}$ do art. $5^{\circ}$ da Lei das PPPs (PAIVA e ROCHA, 2005:30). Isso que aparentemente será bom para o usuário e atende ao princípio da continuidade do serviço público, na verdade, serve para garantir que os investidores financeiros não percam o "benefício das PPPs". Esse dispositivo é visto pelas instituições financeiras interessadas em investir nas PPPs como instrumento importante de garantia dos direitos dos investidores, possibilitando a reestruturação de projetos na iminência de fracasso por ineficiência da gestão do parceiro privado, a bem da verdade, substituindo-o por outra empresa e dando continuidade ao negócio. Por outro lado, esse mecanismo não obsta o direito da Administração Pública de intervir no parceiro privado para garantir a segurança e a continuidade da prestação dos serviços nos casos já previstos na legislação sobre concessões. É esperar a sua aplicabilidade.

O resultado final desses e de outros pontos das PPPs, é uma certa rendição do Estado; ou, em outras palavras, ficam dadas as condições para que esse empreendimento de um capitalismo sem riscos signifique um custo alto para a Nação. Quem quer que se ocupe de ler as colunas de economistas afins ou de estudiosos com o pensamento único e editoriais de jornais como o Estadão, a Gazeta Mercantil ou do Valor Econômico, vai perceber um discurso monocórdico: o Estado tem que dar sempre mais garantias ao capital privado, o Estado tem que garantir os ganhos do investidor privado, o Estado tem que garantir que não haverá riscos para a acumulação do capital; nós não podemos assumir o risco-governo, dizem eles. Está bem claro quem é que pode vir a ser o grande perdedor nessa parceria. Ainda mais quando é o próprio Estado quem vem desmanchando ou deixando em segundo plano os serviços públicos em geral, coisa que vem ocorrendo desde longa data.

Portanto, tais regras presentes na lei das PPPs navegam nas águas desse maravilhoso capitalismo sem risco. É o investidor privado procurando contar com dinheiro público do BNDES, com os recursos enormes dos grandes fundos de pensão (Petros, Previ, Funcef) e com empréstimos internacionais assumidos pelo Estado brasileiro junto ao BIRD, BID e FMI, procurando evitar os riscos. E, como já nos advertia Miliband:

“Tal intervenção do Estado em todos os aspectos da vida econômica não constitui nada de novo na história do capitalismo. Ao contrário, a intervenção estatal presidiu o seu nascimento ou pelo menos guiou e ajudou os seus primeiros passos, não apenas em casos tão óbvios como Alemanha e 
Japão, mas também em todos os outros países capitalistas e jamais deixou de ser de importância vital nas atividades do capitalismo, mesmo no país mais apegado ao laissez-faire e a um rígido individualismo. Não obstante, a escala e a difusão da intervenção do Estado no capitalismo contemporâneo são hoje incomensuravelmente maiores do que em qualquer outra época e sem dúvida alguma continuarão a crescer. E o mesmo se aplica para a ampla rede de serviços sociais, em relação aos quais o Estado assumiu responsabilidade direta ou indireta naquelas sociedades”. (MILIBAND,1974: 20).

A lei das PPPs têm esse caráter do Estado-topa-tudo para atrair capital privado ocioso e garantir seus lucros privados. Essa é uma das razões pelas quais tanto o governo petista como a oposição do PFL e PSDB, por exemplo, em última instância e no essencial, terminaram convergindo, politicamente, na questão das PPPs: tradicionais porta-vozes do neoliberalismo e do neopetismo, tanto na mídia quanto no Congresso Nacional uniram-se na defesa das PPPs; essa coincidência, por si só, já seria motivo de preocupação para a Nação. Joelmir Betting ironiza ao argumentar que "com as PPPs, os petistas admitem, veladamente, a privatização do futuro - eles que não engolem o que já foi privatizado no passado”. (http://www.joelmirbeting.com.br/noticias.asp?IDgNews=2\&IDnews=24562. Acesso em 12 de janeiro de 2004.)

Toda a lei das PPPs está redigida nessa linha de um Estado que tenta seduzir a todo custo o capital para que ele entre em setores, vale repetir, pelos quais não se interessam normalmente e pelos quais só se interessarão se o Estado propiciar e mesmo assegurar lucros altos. Nunca se pode esquecer que obra pública no Brasil costuma ser foco de corrupção; e as PPPs são, vale reiterar, extremamente flexíveis com o setor privado, abrem o flanco para problemas dessa ordem. Por fim, sem dúvida que, o primeiro grande problema das PPPs, o da vassalagem do Estado brasileiro ao capital pela via das facilidades que cria para este e arrocho sobre o usuário final.

\subsection{Comprometimento do Princípio maior do Serviço Público}

O segundo problema é que, da forma como está, a lei das PPPs compromete a própria essência daquilo que norteia o serviço público ${ }^{10}$, o que seja, o princípio do interesse

\footnotetext{
${ }^{10}$ A noção de serviços públicos que estamos adotando é a mais ampla possível, ofertada por José Matias Pereira, no seu livro "Finanças Públicas - a política orçamentária no Brasil”, e destinada a realização das necessidades 
público. O agente que ocupa o papel de responsável pelos empreendimentos de parceria Estado-investidor privado é o setor privado, para o qual o Estado se dispõe, na PPP, a transferir boa parte de suas atribuições. O Estado quer uma determinada estrada funcionando, mas quem executa a obra e quem opera e dá manutenção é o empresário privado. Pois bem, se este entender que não está tendo a taxa de lucro adequada e resolver se retirar, aquela estrada estará comprometida (caso o Estado não entre em campo para garantir seus lucros, para repassar mais dinheiro público para o capital privado); afinal de contas, diz a lei das PPPs:

Art. $4^{0}$ Na contratação de parceria público-privada serão observadas as seguintes diretrizes:

(...)

II - respeito aos interesses e direitos dos destinatários dos serviços e dos entes privados incumbidos da sua execucão;

VI - repartição objetiva de riscos entre as partes;

VII - sustentabilidade financeira e vantagens socioeconômicas dos projetos de parceria.

Aqui não entra apenas o problema do capitalismo sem risco, mas também o dado de que o Estado aparece renunciando a ser gestor de uma política pública; e isso por conta de dois fatores: primeiro que o empresário é o dono da obra e pode sair fora ou pelo menos ameaçar fazê-lo para conseguir ganhos altos com o Estado (este deverá correr contra o prejuízo que é da sociedade), e segundo que o investidor privado, evidentemente, não irá construir estradas, por exemplo, ali onde não haja interesse lucrativo de sua parte. Portanto, é cristalino que do ponto de vista do próprio Direito Administrativo, não temos atendido o princípio do interesse público ${ }^{11}$. Sem buscar ampliar o debate para este ponto, podemos acentuar que o Estado (e podemos indicar o chamado princípio do interesse público do Direito Administrativo) é descrito como a instituição que "pode transcender a racionalidade microeconômica em cujas bases atuam até mesmo as maiores unidades econômicas”, e que

da coletividade, de interesse geral, satisfeitas por meio da atuação, direta ou não, do Estado. Portanto, a primeira noção que esse autor nos informa é que devemos levar em consideração que só existe serviço público porque existe uma necessidade coletiva, isto é, "aquelas que o indivíduo experimenta como membro da sociedade, ou seja, aquelas de interesse geral, satisfeita pelo processo do serviço público” (p. 34). Portanto, o serviço público é entendido pelo autor da seguinte maneira: "sempre que o estado presta um serviço de interesse geral, mobilizando pessoas e bens, para satisfazer as necessidades coletivas, realiza serviço público. Assim, serviço público é todo aquele imprescindível à coletividade e, como tal, declarado pelos poderes competentes, cuja prestação está a cargo do Estado” (p.34).

${ }^{11}$ Aqui poderíamos abrir um novo espaço para discutirmos essa representação do Estado como poder impessoal que não funciona a serviço dos interesses privados de uma classe, mas que se põe como autoridade pública, distante e acima das classes, ou melhor ainda, "estranha" a elas, o que afina em perfeita harmonia com a noção de interesse público do Direito Administrativo, adentrando em um debate muito bem explorado por Márcio Bilharino Neves, em seu livro “marxismo e direito”, da editora Boitempo. 
“pode ser capaz de restabelecer as condições gerais de funcionamento normal da sociedade capitalista”12. Entretanto, as duas ressalvas de Miliband são importantíssimas: a primeira, de que "o principal objetivo do capitalismo é o lucro; e isso, apesar de tudo o que se diga em contrário, não é compatível com boas condições de vida para todos. Pois o capitalismo é essencialmente impelido pela microrracionalidade da empresa, e não pela macrorracionalidade exigida pela sociedade”. E, segundo:

"o desenvolvimento das forças produtivas também foi acompanhado por grandes males sociais (a maioria dos quais precisamente decorrentes da dinâmica da empresa privada), para cujo alívio o Estado foi obrigado a intervir, e a própria capacidade que o Estado tem de fazer isso é reduzida pelo contexto capitalista em que (de bom grado) funciona”. (MILIBAND, 2000:30 e 31).

Portanto, o grande capital só entra quando se trate de empreendimento bem lucrativo. E tais investidores podem, ao assumir o empreendimento, passar a decidir alocação de recursos públicos de médio e longo prazo, especialmente frente a um Estado que adota cada vez menos planejamento governamental. Dificilmente o Estado irá poder direcionar o investimento privado em função do interesse público (macrorracionalidade da sociedade). O setor privado vai buscar a maximização de lucros (microrracionalidade da empresa), ele vai ter interesse por uma determinada estrada, por exemplo, lá no rico estado de São Paulo, mas não pela rodovia estratégica (mas esburacada e praticamente abandonada) que liga Salvador a Brasília. Em outras palavras: a fé do governo no investidor privado é de valor duvidoso. O seguinte exemplo é bastante ilustrativo para compreendermos a antítese entre o interesse público e o interesse privado, ou microrracionalidade da empresa e macrorracionalidade da sociedade, no seio do próprio Estado:

"Uma área diferente, em que a discrepância entre microrracionalidade da empresa e as necessidades da sociedade é escandalosa e prenhe de conseqüências dramáticas é o meio ambiente. A natureza do sistema obriga aqueles que o gerem a tratar a proteção do meio ambiente - no que diz respeito às empresa - como algo de importância secundária, na melhor das hipóteses. Como indivíduos, os homens e as mulheres que dirigem empresas capitalistas podem estar tão ocupados com a ecologia quanto qualquer outra pessoa; como proprietários e dirigentes de empresas, essa preocupação sofre forte inibição, não obstante as intenções pessoais; e os governos também, a despeito do que proclamam, são inibidos pelos obstáculos econômicos e

\footnotetext{
${ }^{12}$ Guilhermo O`Donnell, do livro Bureaucratic Authoritarianism, da Univeridade of Califórnia Press, Berkeley, Los Angeles, 1988, p. 22; apud MILIDAND, 2000, p. 31 
políticos que enfrentam ao tratarem com o vandalismo ecológico gerado pela sede de lucro" (MILIBAND, 2000:34) ${ }^{13}$.

Contar com as PPPs para o espetáculo do crescimento sustentado só vai funcionar em certos casos, e assim mesmo, naquelas ocasiões onde o capital privado estiver lucrando muito e/ou a transferência de renda pública ou regalias para o empreendedor privado estiver fluindo a todo vapor. E é quase certo que o próprio Estado vá perdendo, também por essa via, mais e mais da sua já reduzida capacidade de planejamento na mesma medida em que vá assumindo as PPPs com o entendimento de que elas constituem um mecanismo para potencializar investimentos “com o setor privado assumindo novas funções estratégicas” (Jornal Valor Econômico de 9 de fevereiro de 2004, grifo nosso). De toda forma, mesmo que se desenvolvam projetos de construção de alguma infra-estrutura viária ou de rede de lixo, esgoto ou água, o custo para a Nação em atrair capital ocioso será alto, altíssimo, e será pago pelo conjunto da classe trabalhadora, pelos impostos e por mais endividamento público. Os grandes beneficiários serão as massas de capitais ociosos que andam em busca de investimento aprazível, financiado e garantido regiamente. Por conseguinte, a idéia de interesse público que norteia a noção de serviço público estará comprometido. Não é à toa que Mészáros nos diz que:

\begin{abstract}
“compreensivelmente, portanto, embora o Estado capitalista, visando ao desempenho de suas necessárias funções legitimadoras, possa introduzir corretivos parciais às deficiências dos processos materiais prevalecentes, ele é absolutamente incapaz de produzir as alterações estruturais básicas, até em uma situação de crise grave. E é por isso que as forças que desejam uma mudança estrutural radical devem considerar a necessidade de descartar, em sua totalidade, a formação institucional do Estado”. (MÉSZÁROS, 2005:496).
\end{abstract}

Para, posteriormente, ainda aduzir:

“(...) Portanto, o Estado só pode exercer suas importantes funções controladoras e coordenadoras até o momento em que permanecer compatível com os parâmetros do metabolismo socioeconômico capitalista, mas não além. Tomando-se um exemplo diretamente pertinente ao presente contexto, dada a homologia objetiva das estruturas material-reprodutivas e jurídico-políticas, a articulação institucional do Estado liberal-democrático é inseparável e totalmente inviável sem a articulação material reprodutiva do

\footnotetext{
${ }^{13} \mathrm{O}$ exemplo da não assinatura do tratado de Kioto pelos EUA, com o argumento de que prejudicaria sua economia, dispensa qualquer questionamento sobre a validade do exemplo dado para fins desse texto. 
mercado capitalista, enquanto rede historicamente específica de intercâmbios distributivos profundamente incorporados nas estruturas produtivas do sistema socieconômico em questão. Neste sentido, um deslocamento significativo na estrutura reprodutiva e distributiva do capital em prol de estruturas e processos monopolistas - deslocamento que se torna visível tanto no controle cada vez mais centralizado das unidades particulares da produção social total quanto na operação da rede cada vez mais globalmente interligada dos mercados comercial, de trabalho e financeiro - traz consigo uma implicação prática de longo alcance, segundo a qual as instituições do Estado devem ser ajustadas em consonância com as mesma linhas para poderem enfrentar as exigências das novas condições. Por isso, não foi por acaso que nas últimas décadas o Estado capitalista 'avançado' assumiu cada vez mais um papel de 'facilitador' ou 'possibilitador' de tais transformações. Não apenas removeu sem qualquer cerimônia os obstáculos do caminho da concentração monopolista do poder econômico, obstáculo outrora erguidos pelo Estado liberal-democrático em nome da 'livre concorrência', mas também trabalhou ativamente para a aceleração do processo geral, em harmonia com as exigências emanadas da base material em mutação". (MÉSZÁROS, 2005, p. 496).

Ora, os exemplos anteriormente citados de favorecimento em demasia ao capital privado, contido na lei das PPPs, com o aqui exposto comprometimento da própria essência daquilo que norteia ou orienta o que se chama de serviço público, ambos indicam, na lição acima de Mészáros que:

"a empresa capitalista depende em grau cada vez maior das concessões e do apoio direto do Estado, e só pode preservar seu caráter 'privado' à base desse apoio público. A intervenção estatal na vida econômica significa de fato, em sentido amplo, uma intervenção destinada a ajudar a empresa capitalista” (MILIBAND, 1974:100).

E que o Estado é incapaz de se desvencilhar dessa armadilha, ao contrário, é partícipe ativo dessa estrutura. “A noção de 'Estado do bem-estar' não teve em outra esfera uma significação mais preciosa e oportuna do que aqui: não existem candidatos ao auxílio público mais persistentes do que os orgulhosos gigantes do sistema de empresas privadas”. (MILIBAND, 1974:100). E, embora se expresse "Estado do bem-estar”, como uma mão na luva se encaixa a atual noção de Estado redesenhado pelo neoliberalismo, daí que a antiguidade do texto advém para mostrar que se trata de uma mera metamorfose da eterna dependência do capital. 


\subsection{As PPPs favorecem a uma Política Pública Focal}

Uma terceira questão, intimamente ligada às anteriores, é que as PPPs favorecem claramente um tipo de política pública que já não será mais universal e sim focal. Renuncia-se à universalização na medida em que a política do Estado será a de empenhar-se, acima de tudo, para seduzir e atrair o capital privado para tal ou qual alocação de recursos. Ora, se o critério essencial do capital é o lucro, a obra das PPPs ganham um caráter não mais universal, mas de obra dirigida a focos ou áreas mais lucrativas, ali onde a parceria for boa para o setor privado. E isso não vai necessariamente coincidir com o interesse público e universal do usuário. Os empréstimos de organismos internacionais, aliás, já vêm com esse direcionamento focal. A tendência poderá vir a ser a do financiamento de projetos para determinados setores ou grupos da população, às custas da política pública universal. Aquele sentido mais universal de política pública adotado pelo Banco do Brasil - ou pelos Correios, por exemplo ao implantar uma agência num município pobre, evidentemente não constará da agenda das PPPs, pois o objetivo "lucro” pesará mais forte.

Apenas para reforçar a noção de que as políticas públicas caminham no sentido da focalização e não da universalização, enquanto elemento inerente ao próprio posicionamento de políticas públicas neoliberais, colacionamos manifestação esclarecedora do assunto, inclusive por muito bem sintetizar a compreensão do tema, especialmente frente as chamadas políticas neoliberais de reforma do Estado, que ora estamos fazendo menção:

"Neste processo de redefinição da agenda de Reforma, disputou espaço internamente o ideário neoliberal, que ganhara força nos países centrais e nas agências multilaterais de financiamento. Segundo esta perspectiva, o Estado é essencialmente ineficiente, ineficaz e provedor de serviços de baixa qualidade. A crise econômica - e a crise do Estado - resultam do próprio Estado e de sua intervenção excessiva. A interpretação da crise na América Latina e no Brasil, segundo a leitura neoliberal, foi consubstanciada nas doutrinas do 'Consenso de Washington'segundo as quais foi o próprio Estado Nacional-Desenvolvimentista o gerador da crise nestes países, sendo os programas de ajuste orientados, portanto, para o 'desmantelamento' deste Estado e para reformas que reduzam o tamanho do Estado, desregulamentem a economia e garantam a abertura do mercado (PORTELLA FILHO, 1994). Com relação especificamente à área social, a agenda neoliberal propõe: a) a privatização, através da transferência da produção de serviços públicos para o setor privado lucrativo; b) a descentralização das políticas sociais para as esferas locais de governo, como forma de aumentar a eficiência e a eficácia do gasto público; c) a focalização, orientada para a concentração da ação estatal em determinados serviços (considerados essenciais e não passíveis de oferta pelo mercado) e em segmentos específicos da população, mais 
vulneráveis e expostos a situações de pobreza extrema (DRAIBE, 1993) e d) mudanças na gestão dos programas estatais, de forma a dotá-las da eficiência e eficácia atribuída à gestão privada (FARAH, 1998a). As propostas de corte neoliberal se contrapõem à agenda formulada anteriormente, orientada para a democratização e para construção no país de um Estado do Bem-Estar universalista. No entanto, a crise que atingiu o país desde o início da década de 80 e alterações na economia capitalista mundial, em que se destacam a reestruturação produtiva e a globalização, redefinindo os termos da inserção do Brasil no cenário internacional, vieram colocar novos desafios aos atores que haviam participado internamente da formulação da agenda democrática e estavam engajados com a efetivação da reforma. Assim, ao mesmo tempo que a Constituição de 1988 assinalava a transposição para o plano legal de grande parte da agenda que se fora construindo desde a década anterior, já se assistia a uma reformulação desta agenda, através da incorporação de novos desafios”. (FARAH, 1999:39).

De qualquer modo, retomando o texto sobre a focalização em oposição à universalização, nunca será demais recordar aqui uma questão que paira sobre toda a discussão das PPPs: se tais setores de infra-estrutura e obras públicas fossem “atraentes” para o capital privado, por que este não se ocupou deles até hoje? E por que podem vir a fazê-lo agora? Qualquer resposta a essa pergunta passa pela seguinte constatação: a iniciativa privada só entra em parcerias se o Estado se empenhar em tornar o negócio bem lucrativo. Por essa razão a lei das PPPs é tão porosa aos interesses do setor privado, tão cioso em garantir o sucesso empresarial do empreendimento. E por isso o Estado se propõe a ser um "parceiro" tão generoso com o outro, ao ponto de poder até vir a assumir seu endividamento, como já acentuamos anteriormente. Do ponto de vista do empreendedor privado, o projeto (ou a obra) precisa gerar renda privada, tarifas de interesse mercantil: isso vai pesar mais que o interesse social. A estrada, o porto, a penitenciária terão que gerar lucro, terão que ser rentáveis para os agentes do mercado; afinal de contas, como transcrevemos antes, prescreve o art. $4^{\underline{0}}$ da Lei $n^{\circ}$ 11.079, de 2004, que na contratação de parceria público-privada serão observadas as seguintes diretrizes, estabelecendo no inciso VII a sustentabilidade financeira e vantagens socioeconômicas dos projetos de parceria. 


\subsection{A Mercantilização dos Serviços Públicos}

E aqui nós entramos na penúltima questão, num plano mais geral e, no entanto, pouco destacado na questão das PPPs: elas representam a mercantilização de áreas que antes eram serviços públicos, de Estado. Praticamente só ficam de fora das PPPs a função legislativa, judicial, policial e de regulação. O resto pode ser alvo do lucro privado, pode virar mercadoria. Daí porque estabelece o multicitado art. $4^{\underline{0}}$ da Lei $\mathrm{n}^{\circ} 11.079$, de 2004: Na contratação de parceria público-privada serão observadas as seguintes diretrizes (...) III indelegabilidade das funções de regulação, jurisdicional, do exercício do poder de polícia e de outras atividades exclusivas do Estado. Todavia, o que serão estas outras atividades exclusivas do Estado? Quem diz o que é serviço público? Qual o critério para se afirmar que um serviço é público ou não é? Quais os serviços que podem ser delegados? É fato notório ao estudioso do Direito Administrativo a polêmica, ainda insolúvel até os dias de hoje, sobre o conceito de serviço público. O entendimento será aquele predominante em nossa época, de um Estado mínimo, do tipo: não será delegada a função de defesa (exército, marinha, aeronáutica) ou de expedição de moeda? E a função do banco central? Qual será o critério para a definição?

Sabemos, por experiência histórica, o quanto a experiência da mercantilização da saúde foi negativa para o povo brasileiro, pelo menos para sua maioria mais pobre. Agora as PPPs vão implantar esse processo no tratamento e distribuição da água, no tratamento de esgoto, na vaga da penitenciária e no direito de circulação pelas estradas, afora outras áreas constitucionalmente ou que estão infraconstitucionalmente atribuídas ao Poder Público. Esta é uma questão fundamental: as PPPs significam uma marcha forçada rumo a mercantilização de praticamente todo serviço público. Aqui podemos dizer que como pano de fundo está a questão da intervenção estatal, se nula ou até que grau é aceitável essa intervenção. O problema é que a velha controvérsia entre os intervencionista declarados e seus opositores tem sido e continua a ser perfeitamente válida. É verdade que nenhum político sério - por mais burguês e convencido que esteja das virtudes da empresa privada - desejaria atualmente ou seria capaz de desmantelar a estrutura básica da intervenção estatal. Acontece muitas vezes que são os políticos mais orientados para o capitalismo que vêem com maior clareza como aquela estrutura intervencionista se tornou essencial para a manutenção do capitalismo (MILIBAND, 1974, p. 92). 
Ora, não é necessário que o auxílio estatal seja direto para que seu valor se torne imenso para os interesses capitalistas. Em decorrência das necessidades imperativas da vida moderna, o Estado deve, dentro dos limites que lhe impõe o sistema econômico vigente, empenhar-se e assumir a responsabilidade de inúmeras funções e serviços que ultrapassam o âmbito e as potencialidades dos interesses capitalistas. Ao fazê-lo, como diz Meynaud citado por Miliband, assegura que tais interesses sejam automaticamente beneficiados com a intervenção estatal, pois:

\begin{abstract}
"todas as medidas adotadas pelo Estado para desenvolver e melhorar a economia nacional terminam sempre por beneficiar grandemente aqueles que controlam as alavancas de comando do setor produção-distribuição: quando o Estado abre túneis, constrói estradas ou elevados ou drena pântanos, são antes de tudo os proprietários dos terrenos vizinhos que recebem os benefícios... O conceito de 'tendência preconceituosa do sistema' permite também compreender que as medidas adotadas para remediar as negligências, os erros e abusos do capitalismo resultam em última análise, quando obtêm êxito, na consolidação do regime, pouco importa, nesse sentido, que tais medidas tenham sido adotadas por pessoas simpáticas ou hostis aos interesses capitalistas: acontece que as leis destinadas a proteger os trabalhadores e voltadas contra a sua exploração por parte dos empregadores serão úteis a estes últimos, pois o induzem a realizar um esforço maior no sentido de racionalizar ou mecanizar o processo produtivo" (MILIBAND, 1974, p. 100).
\end{abstract}

E conclui:

\begin{abstract}
"os governos podem estar preocupados apenas com a direção melhor da 'economia'. Mas a descrição do sistema como 'a economia' constitui parte do idioma da ideologia e encobre o processo real. Isso porque o que está sendo melhorado é uma economia capitalista e isso assegura que quem quer que ganhe ou deixe de ganhar, os interesses privados serão aqueles que menos provavelmente perderão” (MILIBAND, 1974, p. 101).
\end{abstract}

Portanto, a contraface dessa mesma moeda é a da evidente redefinição do papel do Estado que está implícita em tudo isso. Por essa via, da entrega ao mercado de portos, aeroportos, estradas, penitenciárias, coleta de lixo, tratamento de água e esgoto, se está dando mais um grande passo na construção do Estado mínimo liberal e abrindo mão, historicamente, não apenas das preocupações sociais e universalizantes da Constituição de 1988, mas também de um constitucionalismo dirigente, na feliz expressão de Canotilho, ou do Estado desenvolvimentista; ou seja, daquele Estado que foi agente da incorporação de grandes massas a certo padrão de consumo e a certos direitos sociais dos anos 1930 até mais ou menos 
a década de 1970, com ênfase na anotação anteriormente feita de compactuação entre o Estado do bem-estar e o próprio sistema capitalista. É que, resta inegável que com a abolição do Estado desenvolvimentista, por essa via se estará polarizando mais ainda a sociedade: a classe média (hoje em franco rebaixamento de sua renda) terá que buscar o mercado para atender suas demandas e o Estado se associa ao mercado para atender um foco aqui, outro ali, no meio mais pobre, enquanto cresce em geral a massa de excluídos da cidadania, de excluídos do SUS (sistema único de saúde) e da universidade pública, por exemplo.

\subsection{A Ciranda Financeira e o Endividamento}

Por fim, a rendição à iniciativa privada que está no corpo da lei das PPPs traduz bem aquela linha do Estado mínimo e da cidadania mínima e sempre em nome de atrair capital privado ocioso, torná-lo lucrativo. Essa é a essência da redefinição do Estado brasileiro, agora tornado um Estado rentista, a serviço da acumulação financeirizada do capital. E esta, afinal, é a questão que está por trás de tantas outras. E a principal fonte de gastos públicos vem a ser, justamente, aquela voltada para atender aos juros e rendimentos demandados pelo capital financeiro. Este é o maior compromisso do orçamento do Estado brasileiro, por exemplo, pagar credores e remunerar capital financeiro. Três notícias são ilustrativas a esse respeito, especialmente porque são oriundas da grande mídia que, como as já transcritas, não se posiciona contra o sistema capitalista e sequer aprofunda suas críticas ao capital financeiro:

Governo anuncia que Brasil vai quitar sua dívida com o FMI - A dívida do Brasil com o Fundo é de US\$ 15,5 bilhões. Brasília - O Brasil vai quitar a sua dívida com o Fundo Monetário Internacional (FMI) no final deste mês. O Ministério da Fazenda divulgou na tarde de hoje que o presidente Luiz Inácio Lula da Silva aprovou nesta terça-feira uma proposta para antecipar para o fim deste ano o pagamento de uma dívida de aproximadamente US\$ 15,5 bilhões do Brasil com o Fundo. Com este pagamento, que será feito até o final deste mês, segundo confirmou o Ministério da Fazenda, o Brasil vai zerar sua dívida com o Fundo. (Estado de São Paulo, Terça-feira, 13 de dezembro de 2005, caderno de economia)

Brasil pagará dívida - Após comemorar o fim da dívida brasileira com o Fundo Monetário Internacional (FMI), o presidente Luiz Inácio Lula da Silva poderá, no ano que vem, quitar os débitos brasileiros com o Clube de Paris. Em outubro, de acordo com dados da Secretaria do Tesouro Nacional, essa dívida era de $\mathrm{R} \$ 5,765$ bilhões. O Clube de Paris é uma instituição informal que reúne países credores. O Brasil tornou-se devedor do Clube em 
1983, quando reestruturou sua dívida externa. (Correio Braziliense, Quintafeira, 21 de dezembro de 2005).

Jogo de juros e troças (Rubem Azevedo Lima) - O presidente Lula ganhou, dia 13, o campeonato brasileiro - talvez mundial - em pagamento de juros da dívida do país. Em nove meses, de janeiro a setembro passado, pagou R\$ 299,4 bilhões. O título foi-lhe concedido pelo Estado de S. Paulo. O campeão anterior, ex-presidente Fernando Henrique Cardoso, diz o Estado, teve seus recordes batidos: em quatro anos do primeiro mandato, pagou R\$ 197,4 bilhões; no segundo, R\$ 268,3 bilhões. Tais cifras mostram: à medida que os anos passam, mais os juros sugam o que o país produz. Essa foi a previsão do economista Marco Antônio Campos Martins, $\mathrm{PhD}$ de economia da Universidade de Chicago. Em 2003, pagamos a esse título - lembra ele - o custo de três usinas de Itaipu; neste ano, ao final, pagaremos o de quatro. De Itaipu em Itaipu não feitas, lá se vai o Brasil. No Correio Braziliense, o economista chamou de jurosduto esse jogo diabólico. Sob Lula, neste ano, prevê-se que pagaremos em juros da dívida mobiliária R\$ 182,5 bilhões. Ou seja: enquanto dormimos - e não adianta ficar acordado -, lá se vão R \$ 5.787,04 por segundo. Nesse minuto, durante o qual o leitor leu este artigo, foram-se R\$347.222,22. Jurosduto é o canal que sangra nossa produção para a especulação mundial. Marco Antônio lembra o dito do assessor de Clinton sobre o problema dos EUA : "É a economia, idiota" - e o adapta para o Brasil: "É a dívida interna, idiota". Pois Lula segue a economia de FHC e a dívida, claro, aumenta. Acha que assim ficaremos ricos. Muita ponte desaba no país. As condições de saúde, educação, segurança e transportes pioram. Palocci e Meirelles se consideram certos. A bomba dessa dívida vai explodir? Mentira. Em 10 anos, diz aquele, estaremos bem. Não é o que pensam no PT Dilma Roussef, Raul Pont e tantos mais. Finda a troça de ministros (o ex-Sérgio Motta e Palocci) irem a comissões sem poder investigatório, para fugir a CPIs, pode ser a hora de os petistas acima de qualquer suspeita - e são muitos - lutarem, com apoio dos brasileiros de boa-fé, de todos os partidos, para tirar o país das profundezas do vórtice econômico em que o meteram. (Correio Braziliense, Segunda-feira, 21 de novembro de 2003, Caderno opinião).

Ademais, denota-se das notícias que o mesmo Estado que alega não ter recursos para bancar projetos, obras e serviços de interesse social ou nacional, mostra-se gastador de recursos bilionários para remunerar com juros, dos mais altos do mundo, aos credores internacionais; e esse mesmo Estado também se mostra um generoso gastador ao procurar garantir os lucros para o grande capital ocioso nas parcerias, assim como arrocha o povo brasileiro e a economia produtiva nacional com um dos maiores fardos fiscais do mundo (para gerar receita que remunere a dívida). Sem falarmos da política de forçar superávits primários maiores do que os exigidos pelo FMI. Dessa forma estamos diante de um Estado rico, mas que queima seu caixa bilionário transferindo maciçamente sua receita para os cofres do capital financeiro, dos credores internacionais. 


\section{CONSIDERAÇÕES FINAIS}

O pano de fundo deste artigo possibilita uma rápida crítica ao papel da relação Estado-capital que está implícita nas PPPs. E, temos como ponto de partida, diante de tudo o que expomos, que a primeira e mais importante conseqüência do comprometimento dos Estados com o sistema de empresa privada e com sua racionalidade econômica é que isso limita enormemente sua liberdade de ação em face de uma multidão de fatos e problemas. Poderíamos novamente aqui transcrever, com maior riqueza de detalhes, a lição, dentre tantas, de Mészáros já exposta no tópico 2.1 do segundo capítulo. Entretanto, vamos chegar novamente neste autor; apenas como forma de convalidar radicalmente tal posicionamento, vamos iniciar pelo reconhecimento expresso da questão por um pensador indiscutivelmente defensor da ordem capitalista: Raymond Aron escreveu que "é evidente que, no regime baseado na propriedade dos meios de produção, as medidas adotadas pelos legisladores e ministros não se oporão fundamentalmente aos interesses dos proprietários” (ARON, 1986: 272). Esta afirmativa, observa ele, é “demasiada óbvia para ser demonstrada”. Ela deveria talvez ser óbvia, mas não parece sê-lo, daí porque procuramos acentuar isso nas várias facetas dos dispositivos legais da legislação das PPPs, que aqui não precisamos revisar, pois a finalidade é retirar qualquer elemento de santidade dessa lei.

De qualquer modo, ampliando o raciocínio, essa referida tendência em favor dos interesses capitalistas tem enormes implicações políticas, justamente porque a solução, ou ao menos o alívio de uma ampla gama de problemas econômicos e sociais exige que o Estado queira agir contra os interesses fundamentais dos capitalistas. Longe de ser uma questão banal, a relutância em fazê-lo constitui um dos fatos mais amplos da vida de nossa sociedade. Aliás, se se dissesse a respeito do Estado que dele, embora confrontado com uma vasta organização criminosa, não se poderia esperar que agisse em oposição fundamental a essa organização criminosa, tal observação seria considerada absurda e seriam requeridas imediatas providências. Assim é que o mesmo raciocínio é válido para a afirmação que Aron tão casualmente apresenta e abandona, inclusive muitos chegam a negá-la como existente.

O que resta consolidado aqui é que a intervenção do Estado na economia, em relação ao interesse capitalista, não está em oposição ou em confronto aos interesses da propriedade. De fato, parece que com o objetivo de se manter os direitos do capitalismo, é que se fazem certas concessões. Mesmo assim, não se deve ignorar o fato de que mesmo os governos conservadores têm sido forçados muitas vezes, principalmente como resultado da 
pressão popular, a agir contra alguns direitos de propriedade e prerrogativas capitalistas. É claro que esses governos dispõem de poder formal para impor a sua vontade ao capital, para impedi-lo de fazer certas coisas e obrigá-los a fazer outras, através do exercício da autoridade. Mas embora seja isso um fato, não se trata absolutamente do fundamental. É que, se por um lado, obviamente que os governos não são completamente impotentes diante do poder do capital, por outro o próprio poder do capital isoladamente considerado na figura de um empresário ou de um banqueiro, por exemplo, por maior que seja o negócio por ele dirigido, não poderia desafiar abertamente as ordens do Estado, nem desrespeitar suas regras e desprezar a lei. O que se quer ressaltar é que não se pode ignorar que a pressão desempenhada por tal capitalista é mais importante e eficaz do que qualquer outra e que somente ele exerce, sem necessitar de organização, campanhas ou lobbies. Trata-se da pressão difusa e permanente sobre os governos e o Estado, decorrente do controle privado dos recursos concentrados, industriais, comerciais ou financeiros. A existência dessa grande área do poder econômico constitui um fato que nenhum governo e Estado, quaisquer que sejam as suas inclinações políticas, pode ignorar na definição de suas políticas e programas e, como assinalamos, tal adentrou na formulação das PPPs.

\footnotetext{
"As relações entre os detentores do poder econômico e os de poder estatal são particularmente importantes. Não se trata em absoluto de um relacionamento fácil e harmonioso. Mas ambos os lados, apesar de todas as diferenças e desacordos, participam de uma sólida parceria. O poder executivo do Estado muitas vezes atua de modo autônomo em assuntos da maior importância, sem consulta a seus parceiros do mundo dos negócios. Os ministros podem de fato sentir pouca simpatia por negócios e pelas pessoas que deles cuidam, demonstrando desdém por seus horizontes limitados; e os homens de negócio, por sua vez, muitas vezes desdenham os políticos que, como dizem os americanos, nunca precisaram enfrentar uma folha de pagamento. As preocupações dos ministros podem estar voltadas para as questões grandiosas como o interesse nacional e a segurança nacional, mas sejam quais forem essas preocupações, suas ações dependem em grau extremo da saúde da economia; e, nas economias capitalistas, essa saúde em grande parte influenciada pela 'confiança do mercado', ou seja, pela confiança que a 'comunidade dos negócios', tanto interna quanto externa, deposita no governo. Cultivar essa confiança tem sido um fator obrigatório e mesmo determinante nos planos e ações dos governos. Em outras palavras, a parceria é tal que o parceiro capitalista é capaz de exercer forte influência sobre o parceiro estatal, simplesmente em virtude do seu poder econômico. O mais notável é o fato de raramente a parceria correr sério risco de dissolver-se devido às ações dos governos”. (MILIBAND, 2000: 37 e 38)
} 
É claro que existem motivações extra-econômicas que também induzem a adoção dessa ou daquela política ou programa público. É evidente que outras pessoas, por exemplo, podem influenciar a tomada de decisão política, inclusive o próprio corpo burocrático do Estado. E há também outros interesses, além dos do capital, que são também levados em conta, por exemplo, em termos nacionais, poder e influência local e estadual não constituem uma questão nula. Novamente o que estamos destacando é que a incidência do poder econômico, social e cultural daqueles que detêm o poder político, quem quer que sejam, provavelmente acatarão sempre os poderosos interesses capitalistas antes de qualquer outro. Lógico que aquelas pessoas que defendem ou não políticas às quais o capital se opõe pode, em certas ocasiões e em determinados lugares, encontrar políticos e funcionários que se coloquem a seu lado em caso de conflito ${ }^{14}$. Mas, como afirma Dahl, também defensor da ordem posta, "seria falso concluir que os assalariados e outros não têm qualquer influência. Mas seria profundamente errôneo afirmar que sua influência coletiva indireta é alta” (DALH, 1971:53).

Ora, é que ao ser considerada a concepção do capitalismo, é fácil compreender porque o Estado deseja auxiliar o capital de todas as maneiras possíveis, muito embora não sinta que isso esteja vinculado a qualquer grau de tendência em relação a determinadas classes, interesses ou grupos. Isso porque se o interesse nacional está de fato indissoluvelmente ligado aos azares da ordem capitalista, uma parcialidade aparente em relação a esta não constitui na verdade parcialidade alguma. Ao contrário, ao servir aos interesses do capital e ao ajudar o capitalista a prosperar, o Estado está realmente desempenhando o seu apregoado papel de guardião do bem de todos. O que está aqui contido é que o Estado aceita a noção de que a racionalidade econômica do sistema capitalista é sinônimo da própria racionalidade e que ela oferece, dentro de um mundo necessariamente imperfeito, o melhor possível de arranjos humanos. Todavia, o problema é que:

\begin{abstract}
"um dos aspectos mais desconcertantes da dominação do capital sobre a sociedade é que sob seu sistema de controle as condições operacionais da produção assumem o caráter fetichista de 'materialidade pura'. Elas são conceituadas como nada além dos meios e do material de produção, a que se devem acrescentar (em relação às suas condições de exercício) tão-somente
\end{abstract}

\footnotetext{
${ }^{14}$ Aqui haveria um enorme espaço para discutirmos a burocracia estatal, o que escaparia do objeto delimitado, inclusive com o reconhecimento de que o Estado moderno precisou de uma burocracia para atender as demandas sociais (prestação de serviços públicos), inclusive sem o clientelismo e patrimonialismo do regime anterior à formação do Estado moderno, na caracterização de que a burocracia adota os princípios definidos por Max Weber de racionalidade, centralidade e impessoalidade, e que a burocracia muitas vezes não segue a linha do governo, tendo disfunções que vão desde a corrupção, privilégios até interesses corporativos, daí que é necessário um controle da burocracia, inclusive como se fosse a projeção do governo. 
as considerações racionalmente incontestáveis da 'eficiência técnica' - que se presume surgirem diretamente da natureza dos fatores materiais. Esta deturpação das condições operacionais esconde com sucesso a normatividade tirânica intrínseca à sua constituição objetiva, tanto como precondição materiais da produção - segundo as quais a própria possibilidade de produção (e de sobrevivência para os trabalhadores) é subordinada à separação ('constitucionalmente' salvaguardada embora de origem extremamente violenta) entre os meios de produção e os produtores reais - quanto como regras funcionais e operacionais exercidas cotidianamente pela autoridade despótica encarregada do controle das empresas capitalistas particulares. À primeira vista, tudo parece ser ordenado e decidido por 'procedimentos racionais', que se supõem surjam diretamente da concentração com total objetividade na realização da 'eficiência máxima' - da qual o sistema pode derivar sua base de justificação. Na verdade, esta aparência fetichista de 'racionalidade', 'objetividade' e 'eficiência' - que encobre a normatividade despótica subjacente - é tão poderosa que (por suprema ironia) até os 'socialistas de mercado' são por ela cativados” (MÉSZÁROS, 2005:512).

E conclui:

"Daí, não se pode sequer pensar na adoção, ainda que parcial, dos métodos e procedimentos da sociedade de mercado capitalista como modelos para o avanço produtivo socialista. Ao contrário, comparando os princípios orientadores dos dois sistemas, detectamos incompatibilidades fundamentais. O capital precisa, apesar dos custos humanos, tratar os recursos humanos, assim como tudo o mais, como 'custos de produção' a serem minimizados e eliminados ao máximo pelo processo de trabalho, como atesta o crescimento perigoso do 'desemprego estrutural' - pela aplicação de sua brutal 'eficiência racionalizadora'. A autoridade reificada do capital só pode ser exercida com esta finalidade” (MÉSZÁROS, 2005:512).

Os críticos da lógica da relação Estado-capital que se colocam pela esquerda,

críticos do funcionamento nefasto dessa relação, que imaginam romper (ou superar a lógica do capitalismo, preservando, no entanto, o próprio capital), parecem acreditar nisso: que a lógica racional dos chamados mercados ${ }^{15}$ pode ser regrada, que o funcionamento irracional da oligarquia (“do mercado" ${ }^{16}$, como mais freqüentemente se diz) pode ser trazido, a partir de leis e regras políticas, a uma razão que não seja a do lucro, a da acumulação capitalista. As

\footnotetext{
${ }^{15}$ Ao citar o tema mercado, ainda que rapidamente, torna-se conveniente defini-lo. Um mercado traduz, de forma permanente e simultânea, as condições de oferta e demanda. É nele que são exercitadas livremente as preferências e as decisões adotadas por compradores e vendedores. O mercado pode ser entendido como um instrumento que viabiliza a interação competitiva do sistema empresarial organizado e ordenando as trocas de bens e serviços (PEREIRA, 1999:23). É esse o sentido de mercado utilizado no todo nesse trabalho.

${ }^{16}$ Como é notório, é inconsistente falar em mercado quando monopólios privados prevalecem no mundo. Mesmo o consumo tem muito pouco de "livre", de regulado pelo mercado. "A parte maior da produção atual vem atender a padrões estabelecidos de consumo e a técnicas predeterminadas de produção, que são em grande medida, se não completamente independentes do mercado. Como isso veio a acontecer? Trata-se precisamente de um resultado da crescente sociabilização objetiva do trabalho" (MANDEL, 1991:29). 
justificativas às PPPs que apresentamos (e outras que são do domínio público a quem minimamente ler os jornais) apontam nessa crença. Tais leis e regras políticas seriam, no caso, patrocinadas pelo Estado, muito embora eles esqueçam, em termos práticos, por exemplo, da necessidade do Estado em obter a “confiança do mercado"; das próprias vantagens econômicas dadas aos capitalistas ou da influência dos organismos internacionais e seus Estados hegemônicos para o endividamento do próprio Estado e da busca do Estado pelo “crédito do mercado" - em face da natureza rentista dos Estados, apresentados no item 2.5 do segundo capítulo.

\begin{abstract}
“Á luz dessa evolução e a despeito de todas as limitações do capitalismo, será racional procurar substituí-lo por um sistema totalmente diferente? Não será mais sensato pressionar no sentido de obter mais reformas dentro do sistema atual, e assim chegar a um capitalismo com rosto mais humano? (...) E não será possível, e até provável, que com o tempo esses avanços venham a transformar ainda mais o capitalismo na direção desejada? (...) Não há dúvida de que esse canto da sereia exerce forte apelo para muitas pessoas de esquerda hoje em dia. Mas existem razões irrefutáveis para resistir a ele. Pois, como veremos depois, as reformas paulatinas não são suficientes para curar os males fundamentais do sistema; (...) A história das reformas do capitalismo mostra que elas sempre foram uma resposta muito especial a 'problemas' específicos, e que sempre foram restringidas pela lógica do capital. Ao invés de buscarem e de colocarem em prática soluções radicais, os governos conservadores sempre encararam as reformas como um meio de evitar transformações radicais, comprando a paz social com concessões. Mas mesmo nos lugares em que foram promovidas por governos socialdemocratas, as reformas não redundaram na abolição das características essenciais do capitalismo. Nem é para menos, visto que raramente era essa a intenção”. (MILIBAND, 2000:26).
\end{abstract}

Diante da relação Estado-capital que estamos apresentando, aqui fica posto um problema: quem vai disciplinar quem? Pensadores, políticos, formadores de opinião pública visceralmente crítico ao capitalismo selvagem e seus males, se caracterizam por propor o remédio da regulação que controle institucionalmente os movimentos do capital, sendo que, em suas propostas, nada mencionam sobre a promíscua relação Estado-capital e da necessidade deste de sobreviver às custas da intervenção econômica. E, o que é pior, esquecem de questionar, como nos disse Mészáros, que a racionalidade do sistema capitalista reduz tudo a uma concepção de “custos de produção”, derivada da eficiência racionalizadora, apesar dos custos humanos. Estamos diante do que também foi apresentada (vide tópico 2.2 do segundo capítulo) de microrracionalidade da empresa (busca do lucro) diante da macrorracionalidade da sociedade. 
Por mais que se planeje ou se pretenda "regular” o mercado, o lucro continuará sendo um "planejador" fundamental da economia, daí a sua presença marcante para inviabilizar e prejudicar o Estado enquanto formulador e responsável pelas políticas públicas, como no caso das PPPs - na crença de que este Estado atende ao interesse público. Por outro lado onde vai residir a força de um Estado que se encontra refém e completamente atravessado pela lógica e pelos interesses concretos, de classe, do grande capital? E mais que isso: se é certo que o Estado nessa estagnação capitalista sobrevive às custas de empréstimos privados, dos empréstimos do capital financeiro (a quem oferece juros altíssimos, e assim constrói boa parte da dívida pública) e de mais impostos, os indicadores da crise também revelam que o capital financeiro depende inegavelmente do Estado para sobreviver; senão como explicar o crescente intervencionismo público, as injeções de bilhões e bilhões de dólares para salvar a oligarquia financeira (o "mercado de capitais")? Senão como entender que as encomendas estatais sejam completamente relevantes para o grande capital (o Estado é um grande consumidor)? Senão, como entender a implantação e as demasiadas vantagens para a contratação via PPPs?

De qualquer maneira, estas foram algumas considerações que, em todo caso, não podem minimizar o fato de que no bojo da relação Estado-capital, a solução presente nas parcerias, baseada em sua tendenciosamente limitada crítica política, busca o melhor dos dois mundos: um controle sobre a economia de mercado que se responsabilizaria, por exemplo, pela infra-estrutura do país, e ao mesmo tempo se eximiria das responsabilidades públicas, oriundas das necessidades coletivas que fazem brotar a noção de serviço público ${ }^{17}$, inclusive (quem sabe) atribuindo os fracassos reais ou potenciais as disfunções inevitáveis do mecanismo de mercado. Trata-se de um autêntico mundo de fantasia.

\section{REFERÊNCIAS}

ALVES, Alaôr Caffé et al. Direito, sociedade e economia: leituras marxistas. São Paulo: Manole, 2005.

\footnotetext{
${ }^{17}$ Vide nota $\mathrm{n}^{\circ} 9$. 
ARON, Raymond. Classe social, classe política, classe dirigente. Trad. Sérgio Bath. 3. ed. São Paulo: Martins Fontes, 1990.

BETING, Joelmir. Quadratura do Círculo. Disponível em:

$<$ http://www.joelmirbeting.com.br/noticias.asp?IDgNews=2\&IDnews=24562 > . Acesso em: 12 jan. 2004.

BESSA, Paulo. A Teoria Geral do Direito e o Marxismo. Rio de Janeiro: Renovar, 1989.

BLANCHET, Luiz Alberto. Parcerias público-privadas. Curitiba: Juruá, 2005.

BOTTOMORE, Tom (Ed.). Dicionário do pensamento marxista. Rio de Janeiro: Jorge Zahar, 1988.

BRASIL. Lei Federal nº 11.079, de 30 de dezembro de 2004.

BRASIL. Ministério do Planejamento. Disponível em:

<htpp://www.planejamento.gov.br/planejamento_investimento/conteúdo/notícias?>. Acesso em 09 de set. 2005.

CHESNAIS, François. A mundialização do capital e a acumulação financeira neoliberal: elementos de ruptura. In: O Olho da História: Revista de História Contemporânea, Salvador, v. 1, n. 5, set. 1998.

DAHL, Robert A. Política: participação e Oposição. apud Antônio Carlos Cintra. Brasília: Câmara dos Deputados. Democracia na América Latina, estudo, novembro de 2000.

FARAH, Marta F. Santos. Parcerias, novos arranjos institucionais e políticas públicas locais. São Paulo: Fundação Prefeito Faria Lima - CEPAM. O município no século XXI: cenários e perspectivas, 1999.

Reforma de Políticas Sociais no Brasil: iniciativas recentes de governos estaduais e municipais. Paper apresentado ao Seminário Internacional Reestruturação e Reforma do Estado: Brasil e América Latina no Processo de Globalização. FEA-USP, 18-21 maio de 1998. Distribuição no Senado Federal.

HORBACH, Carlos Bastide. Parceria público-privada: aspectos gerais. Texto relativo à exposição realizada na Mesa de Debates do Instituto Pimenta Bueno - Associação Brasileira dos Constitucionalistas do dia 28 de setembro de 2004, em São Paulo, disponibilizada pelo próprio autor.

KPMG Structured Finance. PPP Programas de Parceria Pública, 2002. 
MANDEL, Ernest. Teoria marxista do Estado. Trad. M. Reis. Lisboa: Antídodo, 1977. (Coleção Argumentos, v. 3).

Socialismo versus mercado. São Paulo: Ensaio (Cadernos Ensaio, pequeno formato, v. 8 Trad. J. Almeida de Souza jr. De In defense of socialist planning, New Left Review, 1986), 1991.

MÉSZÁROS, István. O Poder da ideologia. São Paulo: Boitempo editorial, 2005.

MILIBAND, Ralph. O Estado na sociedade capitalista. Rio de Janeiro: Jorge Zahar, 1974.

. Socialismo \& Ceticismo. São Paulo: Fundação Editora UNESP e EDUSC (editora da Universidade do sagrado Coração), 2000.

MIGALHAS: pílulas de informação. Disponível em:

$<$ http://www.migalhas.com.br/mig_imprimir_sem_imagem.aspx?cod=16160>. Acesso em: 07 set. 2005.

NAVES, Márcio Bilharino. Marxismo e direito: um estudo sobre Pachukanis. São Paulo: Boitempo editorial, 2000.

PAIVA, Silvia M. Caldeira; ROCHA, C. Alexandre. Parceria público-privada: o papel do Senado Federal na discussão e aprovação da lei no 11.079, de 2004. Brasília: Coordenação de Estudos da Consultoria Legislativa do Senado Federal, 2005. Texto para discussão.

PEREIRA, José Matias. Finanças públicas: a política orçamentária no Brasil. São Paulo: Atlas, 1999.

PORTELLA FILHO, Petrônio. O ajustamento na América Latina: crítica ao modelo de Washington. São Paulo: Lua Nova, 1994.

BRASIL pagará dívida. Correio Braziliense, Brasília, 21 dez. de 2005. A-13.

JOGO de juros e troças (Rubem Azevedo Lima). Correio Braziliense, Brasília, 21 nov. 2003. Caderno Opinião.

INFRA-ESTRUTURA: governo define fundo de R \$ 4,2 bi para as PPPs. Correio Brasilienze, Brasília, 16 set. 2005.

SADER, Emir. Estado e política em Marx. São Paulo: Cortez, 1993. 
SUNDFELD, Carlos Ari (Org.). Parceria Público-Privada. São Paulo: Malheiros, 2005.

WERNECK, Rogério L. Furquim. PPP, uma velha idéia em nova embalagem: possibilidades e limitações da proposta de parceria público-privada. Estado de São Paulo, 24 out. 2003.

\section{Prismas: Direito, Políticas Públicas e Mundialização}

http://www.mestrado.uniceub.br/revistamestrado

Artigo recebido em 15/03/2006 e aceito para publicação em 17/05/2006

A revista Prismas: Direito, Políticas Públicas e Mundialização destina-se à publicação de artigos relacionados com a área jurídica, tem o propósito de difundir as reflexões dos pesquisadores, docentes, discentes, profissionais e estudantes da área de Ciências Jurídicas.

Os artigos são avaliados mediante processo de revisão por pares e deverão contemplar as reflexões que dizem respeito ao estudo do Direito, das Relações Internacionais e das Políticas Públicas. 